\title{
6
}

\section{ELF AWARENESS FOR TEACHER EDUCATION IN ITALY: ATTITUDES AND ACTIONS}

\section{TOMADA DE CONSCIÊNCIA SOBRE O ILF NA FORMAÇÃO DOCENTE NA ITÁLIA: ATITUDES E AÇÕES}

\author{
Enrico Grazzi ${ }^{1}$ \\ Roma Tre University, Italy \\ Lucilla Lopriore ${ }^{2}$ \\ Roma Tre University, Italy
}

\begin{abstract}
The spread of English as the world's primary lingua franca (ELF) poses some challenging questions about the impact of ELF on English language teaching (ELT). The gap between the dominance of native-speaker oriented institutional curricula and the emergence of variable, context-bound forms of English in multilingual and multicultural communicative settings is plain to see, opening up an opportunity for researchers to explore new directions in which future studies might be heading in order to implement an ELF-aware pedagogic approach to English. The aim of this article is to analyse a selection of relevant data that have been collected through a teacher survey on the state of the art as regards ELT. The survey was administered in Italy (mainly at upper and lower secondary school level). In particular, the authors focus their attention on issues such as learners' errors, standard and non-standard English models, teachers' attitudes and beliefs, the use of authentic materials, the encouragement of learners' creativity, learner assessment and evaluation. This study, part of an Italian national research project, has been carried out by one of the three teams constituting the study group, the one from Roma Tre University, whose main objective is to take into consideration the changing scenario of Global Englishes and open new paths to revisit teachers', learners' and publishers' beliefs and offer possible perspectives about classroom practices, assessment and evaluation, and material development.
\end{abstract}

Keywords: ELF; ELF awareness; attitudes; beliefs; teacher education.

enrico.grazzi@uniroma3.it

2 lucilla.lopriore@uniroma3.it 
Resumo: $O$ avanço do inglês como principal língua franca mundial (ILF) traz alguns questionamentos sobre o impacto do ILF no Ensino de Língua Inglesa (ELI). A lacuna existente entre a prevalência dos currículos institucionais com base no modelo do falante nativo e o surgimento de formas variáveis e localizadas de inglês em contextos comunicativos multilíngues e multiculturais está cada vez mais visível, tornando-se uma oportunidade para pesquisadores explorar novos caminhos que estudos futuros devem estar trilhando com vistas à implementação de uma abordagem pedagógica voltada sob a perspectiva do ILF. O objetivo deste artigo é analisar a seleção de dados significativos que foram coletados através de uma pesquisa com professores sobre o estado da arte em ELI aplicado na Itália (principalmente nos níveis fundamental e médio). Especificamente, os autores centram a atenção em questões como erros dos aprendizes, modelos padrão e não-padrão de inglês, o uso de materiais autênticos, estímulo à criatividade dos alunos e avaliação de aprendizagem. Este estudo, como parte de um projeto de pesquisa nacional, foi conduzido por um dos três grupos que fazem parte da equipe, o da Universidade Roma Ter, cujo objetivo principal é abordar o cenário de Ingleses Globais e abrir novos caminhos para revisitar crenças de professores, alunos e editores, oferecendo, assim, possíveis perspectivas sobre práticas pedagógicas, avaliação e desenvolvimento de materiais.

Palavras-chave: ILF; Tomada de consciência sobre o ILF; atitudes; crenças; formação docente.

\section{INTRODUCTION 3}

This contribution is meant to illustrate and discuss some of the findings of

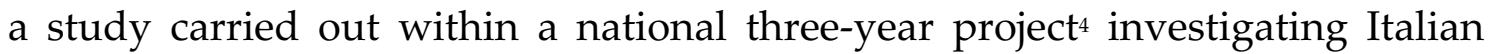
teachers' knowledge of and attitudes to the new status of English, specifically to World Englishes (WE) and English as a Lingua Franca (ELF) in domain-specific contexts of intercultural communication.

\section{Research aims \\ The main aims of the Roma Tre University Unit ${ }^{5}$ were to:}

3 This contribution was jointly conceived and developed by both authors. Specifically, both authors wrote the Introduction and the Conclusions. Section 1 was written by E. Grazzi, while section 2 was written by L. Lopriore.

4 The Italian national research project, PRIN 2015: Prot. 2015REZ4EZ English as a Lingua Franca in domain-specific contexts of intercultural communication: a cognitive-functional model for the analysis of ELF accommodation strategies in unequal migration contexts, digital-media virtual environments, and multicultural ELF classrooms. Composed by:

Research Unit 1: Università del Salento Principal Investigator: Prof. Maria Grazia Guido

Research Unit 2- Università di Verona: Prof. Roberta Facchinetti

Research Unit 3- Università Roma Tre: Prof. Lucilla Lopriore

5 Lucilla Lopriore (Roma Tre University), main investigator, Enrico Grazzi, (Roma Tre University) Marina Morbiducci, (Roma Sapienza) David Newbold, (Ca' Foscari, Venice University) and Silvia Sperti (Roma Tre University). 
- investigate current practices in the teaching of English and in the education of future English teachers within the changes occurring since the rapid spread of WE and the emergence of ELF in an era of widespread multimedia use;

- investigate how WE and ELF awareness may become part of teaching and learning practices in Italian contexts;

- develop an ELF awareness perspective as well as an ELF oriented pedagogy in teacher education, in classroom practices, syllabi and materials use, assessment and evaluation development;

- identify a new construct in English language teacher education.

\section{Research Design}

The research design envisaged a series of yearly actions in order to respond to the Roma Tre research unit's main aims and questions. Preliminary to any sort of action was the need to investigate the current practices of English language teaching and education in Italy, as well as to learn more about teachers' understandings of the type of English competence to be achieved by their learners, their attitudes in a time of change where English is no longer a 'foreign' language, but largely the result of several linguacultural exchanges while being more and more used as a 'lingua franca'. The study team thus developed the most suitable sampling design to identify the teachers to be interviewed, the statistical and the operational design to select the items of inquiry needed, the most appropriate tools and the type of analysis to be used. As a consequence, the resulting survey included the development of specific tools, namely an on-line questionnaire, the type of administration tool 6 , and a protocol for a focus group follow up with the respondent teachers.

In the first year of the research, the teachers' questionnaire was administered to a sample of English language teachers in Italy. Following actions in the second year were aimed at studying the use of ELF in multilingual classrooms and in on-line teaching and training contexts. The third year was aimed at developing an educational model within an ELF-aware perspective. Some of the preliminary findings are presented and discussed in this contribution.

6 The questionnaire was administered via SurveyMonkey [https://it.surveymonkey.com/]. 


\section{The questionnaire}

The questionnaire was organized into three main sections: the first one was mainly aimed at gathering respondents' professional background information, the second one - English and beyond - was aimed at finding out teachers' familiarity with and understanding of specific terminology related to ELT inclusive also of new notions such as ELF etc., while the third one - English language teaching: current practices - was meant to elicit respondents' comments on their daily teaching routine as well as to uncover their attitudes and beliefs about ELT.

The questionnaire was administered on-line to a sample of English language teachers in Italy in two subsequent administrations: the first one in May 2017 and the second one in September 2017.

\section{Responses}

As shown in Table 1, 196 respondents participated in this survey altogether. The majority of them were female $(92.86 \%)$, while only a minority $(7.14 \%)$ were male. This unbalanced gender distribution is in line with data regarding the population of Italian teachers across different school levels, as the OECD's (2019: 406) study Education at a Glance 2018 reports. According to this research, which refers to data that were collected in 2016, almost eight Italian teachers out of ten were female, while the OECD average is seven out of ten. This datum is also consistent with the fact that $91 \%$ of Italian freshmen in areas connected to pedagogy are female, as reported by the OECD's study (2016: 7) Uno sguardo sull'istruzione 2016 [Education at a Glance 2016].

\section{Table 1}

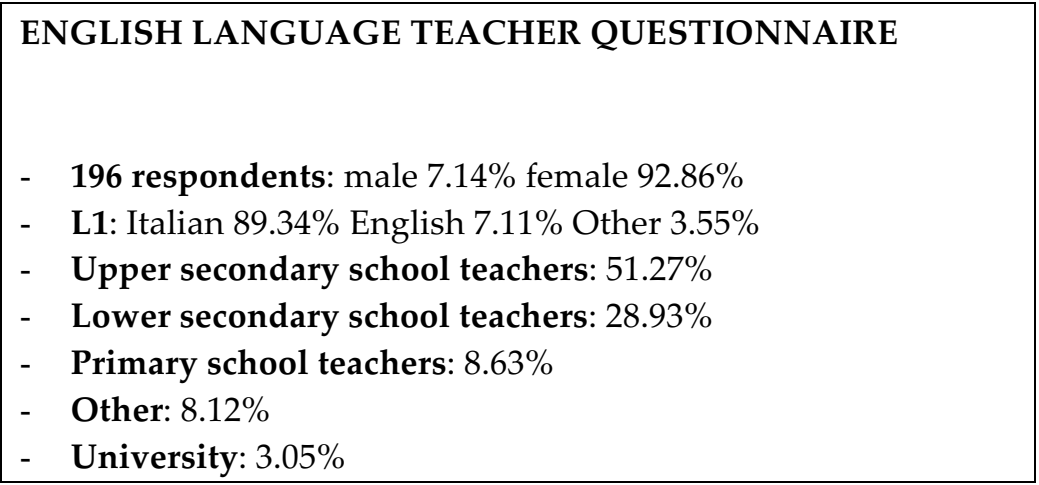

Data in Table 1 also show that most respondents speak Italian as their first language (89.34\%), even though a minority speaks English as their mother tongue 
(7.11\%), and the rest speaks another L1 (3.55\%). As regards the distribution of respondents by level of education, data show that the majority of them teach English at upper secondary school (51.27\%) and lower secondary school $(28.93 \%)$, while a minority teaches at primary school $(8.63 \%)$ and at University $(3.05 \%)$. It should be observed, however, that the variability of the composition of the sample essentially depends on how the research team selected and contacted the respondents, our key criteria being that: a) the survey should be primarily concerned with the core group of Italian teachers of English at upper and lower secondary school levels; and b) that respondents should be representative of the Italian geographical macroareas, namely the North-West, the North-East, the Centre, the South and the South-Islands. For this reason, we asked first of all three Italian non-profit associations of language teachers ${ }^{7}$ if we could administer our questionnaire to their members, who are mainly highschool, middle-school and primary-school teachers, located all across the country. Nevertheless, the aim of the research team was not to create a statistical sample based on the geographical distribution of teachers of English working in different parts of the country in Italy, but rather to consult as wide a network as possible of national contacts8.

\section{Modes of data analysis}

The authors have selected data from respondents' answers that may well illustrate the teachers' attitudes concerning the impact of the global dimension of English on mainstream English language teaching (ELT). The following sections will focus on Question n. 21 (Think about your own teaching context(s). Please state whether you agree or disagree with the following statements about English Language Teaching. (Please use the following scale from 0 - (strongly disagree) to 5 - (strongly agree)), particularly as regards some crucial issues, including learners' preference

7 1) ANILS (Associazione Nazionale Insegnanti Lingue Straniere) is an Italian non-profit association of teachers of foreign languages, accredited by the Italian Ministry of Education (MIUR). Available at: <http://www.anils.it/wp >. Access: Aug 01, 2019.

2) Lend-lingua e nuova didattica is an Italian cultural association of language teachers accredited by the Italian Ministry of Education (MIUR). Available at: <www.lend.it/eu>. Access: Aug 01, 2019.

3) TESOL Italy (Teachers of English to Speakers of Other Languages) is an Italian non-profit association of teachers of English accredited by the Italian Ministry of Education (MIUR), and an affiliate of TESOL International. Available at: $<$ http://tesolitaly.org/new $>$. Access: Aug 01, 2019.

8 A more detailed description regarding the demographics of the survey is available in Grazzi and Lopriore (2019). 
for native teachers of English (Q21.1), learners' errors (Q21.2), the standard English (SE) model (Q21.4), new language forms (Q21.5), the successful user of English (SUE) model $^{9}$ (Q21.6), the use of authentic materials containing nonstandard forms of English (Q21.9), learner assessment and evaluation (Q21.12). Data have been grouped into two sets, according to their topical area.

\section{STANDARD ENGLISH ${ }^{10}$ VERSUS ELF IN THE ENGLISH CLASSROOM}

This section discusses the responses from the following subquestions of the teacher questionnaire: Q21.2, Q21.4, Q21.5 and Q21.12. Respondents were asked to state whether they agreed or disagreed with the statements contained in each item using a scale from 0 (strongly disagree) to 5 (strongly agree).

- Q21.2 Teachers should correct learners' errors in class because these tend to cause a breakdown in communication.

This item is about a critical issue the research team wanted to explore in our questionnaire for teachers of English, that is, their attitude towards learners' deviations from standard norms (i.e. errors). Data in Table 2 indicate that most respondents (57.86\%) tend to avoid extreme forms of agreement or disagreement, and express a less radical stance, with values ranging mostly between 2 and 3 . This could be interpreted as a form of teachers' flexibility when they have to decide if and when learners' errors should be corrected. This gives them broad discretion in setting priorities as regards learners' accuracy versus learners' fluency in English. We may argue that this is a fundamental principle in communicative language teaching (CLT), which incidentally is also in line with the tenet of intelligibility that is inherent to ELF theory. As regards pronunciation, for instance, Jenkins (2000, p. 166) suggests that, within a pedagogic environment, learners should be encouraged to implement accommodation strategies whenever inter-speaker segmental and suprasegmental deviations

9 In: Prodromou, L. English as a Lingua Franca, London: Continuum, 2010, p. ix.

10 The notion of Standard English (SE) is quite a controversial one that has been widely discussed by linguists, since the 1980's. There are several definitions that are focused on different features, either linguistic, or socio-linguistic. For a much more detailed account of the debate around the issues related to the nature of SE and the reality of native and non-native varieties of English, see Seidlhofer (2003, p. 7-32). 
from standard norms may hinder communication and intelligibility: "[...] speakers need to develop the ability to adjust their pronunciation according to the communicative situation in which they find themselves. [...] In other words, they need to be able to 'accommodate' (or more specifically 'converge') towards their listeners."

We may therefore assume that even though respondents normally adopt SE as their reference model in ELT (as will be shown in the following point), they are prone to tolerate students' errors as part of the learning process and opt for a selective approach to correction, whereby learners' achievement of their pragmatic goals in communication takes priority over conformity to standard phonological and lexicogrammar norms.

Data in Table 2 below also show that the percentage of respondents who expressed a more marked disagreement with the statement in Q21.2 (columns 0 and 1), or a more marked agreement with it (columns 4 and 5) is essentially the same: $20.71 \%$ and $21.42 \%$, respectively. This indicates that more extreme positions regarding the correction of learners' errors should not be considered to be negligible.

Table 2

\begin{tabular}{|l|c|c|c|c|c|c|c|}
\hline & $\begin{array}{c}\mathbf{0} \\
\text { (Strongly } \\
\text { disagree) }\end{array}$ & $\mathbf{1}$ & $\mathbf{2}$ & $\mathbf{3}$ & $\mathbf{4}$ & $\begin{array}{c}\mathbf{5} \\
\text { (Strongly } \\
\text { agree) }\end{array}$ & Total \\
\hline $\begin{array}{l}\text { Q21.2 Teachers } \\
\text { should correct } \\
\text { learners' errors } \\
\text { in class because } \\
\text { these tend to } \\
\text { cause a } \\
\text { breakdown in } \\
\text { communication }\end{array}$ & $\begin{array}{c}3.57 \% \\
5\end{array}$ & 24 & 39 & 42 & 22 & $8.71 \%$ & 140 \\
\hline
\end{tabular}

- Q21.4 Non-native English language teachers should adopt standard English as their target model

As we can see in Table 3, data show that most respondents expressed great appreciation for the traditional standard English model in ELT. If we combine the figures of those who answered 3, 4 or 5, we have a total percentage of $71.43 \%$ of those who agree or strongly agree with the statement in Q21.4, against a minority of $28.57 \%$ of those who answered 0,1 or 2 to express their disagreement. 
Provided that our sample is not representative of all teachers of English in Italy, these results suggest that native-speakerism (HOLLIDAY, 2005) is still heavily influencing the orientation of the target L2 pedagogical model in this country. This entails that it is still the monolithic conception of standard English that inspires language teachers and permeates the Italian educational approach to ELT, notwithstanding the plurilithic dimension of English (PENNYCOOK, 2009) as the primary global lingua franca, and given the high variability factor that is intrinsic to WE. Everything said, however, it would be misleading to portray language teachers as the committed gatekeepers of orthodoxy, for the teacher survey has revealed that in fact they tend to encourage learners' linguistic creativity (PITZL, 2012) as part of the communication process, as we shall see in the next point.

Table 3

\begin{tabular}{|c|c|c|c|c|c|c|c|}
\hline & $\begin{array}{c}0 \\
\text { (Strongly } \\
\text { disagree) }\end{array}$ & 1 & 2 & 3 & 4 & $\begin{array}{c}5 \\
\text { (Strongly } \\
\text { agree) }\end{array}$ & Total \\
\hline $\begin{array}{l}\text { Q21.4 Non- } \\
\text { Native English } \\
\text { language } \\
\text { teachers } \\
\text { should adopt } \\
\text { standard } \\
\text { English as } \\
\text { their target } \\
\text { model }\end{array}$ & $\begin{array}{c}7.14 \% \\
10\end{array}$ & $\begin{array}{c}6.43 \% \\
9\end{array}$ & $\begin{array}{c}15.00 \% \\
21\end{array}$ & $\begin{array}{c}25.00 \% \\
35\end{array}$ & $\begin{array}{c}27.86 \% \\
39\end{array}$ & $\begin{array}{c}18.57 \% \\
26\end{array}$ & 140 \\
\hline
\end{tabular}

- Q21.5 Teachers should encourage students to experiment with new language forms to communicate meaning

Statements in Q21.4 and Q21.5 were sequenced together on purpose. They represent two opposite attitudes in language teaching: the former tends to reaffirm the exonormative role of standard English, which is conceived of as the prototypical model of correct English; the latter, instead, emphasises teachers' open approach towards learners' natural tendency to resort to language creativity and communication strategies to carry out verbal interaction successfully. Consequently, one would expect answers to Q21.4 and Q21.5 to be diametrically opposed. Instead, data in Table 4 show that none of the respondents expressed their strong disagreement with the statement in Q21.5 $(0 \%$ answered 0 o 1), a minority expressed a mild disagreement (2.14\% answered 2 ), $13.57 \%$ 
answered 3, expressing a mild agreement, and finally a large majority $(84.28 \%)$ expressed their strong agreement answering 4 or 5 .

At a first glance, results in Table 3 and Table 4 might be considered totally contradictory and inconsistent: on the one hand, respondents are openly supportive of native-speaker standards in ELT; while on the other, they do not disregard students' attempts to learn English even through deviations from traditional standard norms. To analyse these apparently conflicting results, it seems appropriate to take into consideration Vygotsky's (1978) concept of internalization in second language development. As Lantolf and Thorne (2006, p. 176) explain: "[...] internalization occurs through imitation, which is not a mindless copying activity, but an intentional, complex, and potentially transformative process. It is a uniquely human capacity that is implicated phylogenetically and neuropsychologically in language acquisition." Hence, we may conclude that the learning process that normally occurs within the English classroom depends on the dynamic interplay between the educational reference model (in this case the idealised competent native speaker) and the linguacultural, social, contextual factors that characterise the learning environment. In this view, L2 language learning entails a transformative potential that leaves room for students' experimentation and creativity. Presumably, what the teacher survey has shown through Q21.5 is that respondents either have a clear understanding of, or sense the importance of learners' agency, i.e. their ability to transform target language forms and meanings and adapt them to their linguacultural identity.

On reflection, we could say that Vygotsky's process of internalisation should apply also to the natural emergence of ELF in non-educational settings. Therefore, it is reasonable to hold that nonconformity is a typical feature of second language development, regardless of the distinction between EFL ${ }^{11}$ and ELF. With Grazzi (2018, p. 425), we could then say that the learner's performance represents the point of convergence between the English of the subject and the English used in authentic multilingual and multicultural environments.

11 English as a foreign language, that is the language that belongs to its native speakers. 
Table 4

\begin{tabular}{|l|c|c|c|c|c|c|c|}
\hline & $\begin{array}{c}\mathbf{0} \\
\text { (Strongly } \\
\text { disagree) }\end{array}$ & $\mathbf{1}$ & $\mathbf{2}$ & $\mathbf{3}$ & $\mathbf{4}$ & $\begin{array}{c}\mathbf{5} \\
\text { (Strongly } \\
\text { agree) }\end{array}$ & Total \\
\hline $\begin{array}{l}\text { Q21.5 Teachers } \\
\text { should } \\
\text { encourage } \\
\text { students to } \\
\text { experiment with } \\
\text { new language } \\
\text { forms to } \\
\text { communicate } \\
\text { meaning }\end{array}$ & 0 & $0 \%$ & $2.14 \%$ & $13.57 \%$ & $40.71 \%$ & $43.57 \%$ & 140 \\
\hline
\end{tabular}

- Q21.12 When it comes to English language learners' assessment and evaluation, teachers should only refer to standard English

Table 5 shows that data are almost equally distributed between teachers who express a variable degree of disagreement with the statement in Q21.12 ( $47.86 \%$ answered 0,1 or 2), and those who instead express a variable degree of agreement (52.14\% answered 3, 4 or 5). This seems to indicate that although most respondents believe that standard English is the appropriate reference model in ELT (see Table 3), the leading principle to assess and evaluate learners' competences should not exclusively be based on the students' conformity to the norms. These results are consistent with figures in Q21.2 (Table 2) and Q21.5 (Table 4), so we may assume that most respondents adopt a critical stance towards native-speakerism whenever learners' performance is at stake. This, we should observe, is not only an essential feature of CLT, that prioritises fluency over accuracy, but also of ELF theory, which legitimates variability in non-native Englishes.

In conclusion, answers to item Q21.12 suggest that respondents do not have a clearcut, united position on learners' assessment and evaluation. This shows that perhaps language teachers are getting ready to make a "necessary conceptual shift" (JENKINS, 2007, p. 16) towards an ELF-aware approach to ELT. As Newbold (2018: 41) suggests: “[...] the time seems to have come to abandon native speaker standards in order to provide valid and meaningful assessment of the use of English in an international ambit, in which the language and strategies of native speakers may actually hinder communication. [...] teachers and testers (and ultimately international examining boards) will need to develop 'ELF aware tests' $[\ldots]^{\prime \prime}$ 
Table 5

\begin{tabular}{|l|c|c|c|c|c|c|c|}
\hline & $\begin{array}{c}\text { 0 } \\
\text { (Strongly } \\
\text { disagree) }\end{array}$ & $\mathbf{1}$ & $\mathbf{2}$ & $\mathbf{3}$ & $\mathbf{4}$ & $\begin{array}{c}\mathbf{5} \\
\text { (Strongly } \\
\text { agree) }\end{array}$ & Total \\
\hline $\begin{array}{l}\text { Q21.12 When } \\
\text { it comes to } \\
\text { English } \\
\text { language } \\
\text { learners' } \\
\text { assessment } \\
\text { and } \\
\text { evaluation, } \\
\text { teachers } \\
\text { should only } \\
\text { refer to } \\
\text { standard } \\
\text { English }\end{array}$ & 18 & 22 & 27 & 31 & 29 & 13 & 140 \\
\hline
\end{tabular}

2 EMERGING TEACHERS' ATTITUDES AND PERCEPTIONS

The four subquestions $-.1, .4, .9, .6$ - presented and discussed in this second part rely upon teachers' personal perceptions and they all are statements linked to Question 21 (Think about your own teaching context(s). Please state whether you agree or disagree with the following statements about English Language Teaching), but they have been grouped together because they were all meant to trigger teachers' personal stance and positioning as for diverse issues related to their attitudes and deeply held beliefs regarding the English language and ELT and to their perception of language (LLURDA, 2005). Some studies (BRAINE, 1998; LLURDA, 2005; BAYYURT, 2006, PAVLENKO, 2007) have highlighted the close link between second language non-native speaker teachers (NNSTs) and their own previous experiences as second language learners, as a way to understand their students' challenges and strategies in second language learning (SLL). Teachers share concerns and preferences through their SLL memories and may thus better perceive their learners' attitudes and beliefs. Personal and biographical aspects of teaching related to what teachers do and think in their life experience have become increasingly important in studies on the 'learning teaching' process (FREEMAN; RICHARDS, 1996; GOLOMBEK, 1998; FREEMAN, 2016; LOPRIORE, 2019a/b).

While there have recently been numerous large-scale research studies investigating teachers' attitudes, practice, beliefs and the impact on their identity 
(cfr. OECD, TALIS, 2009), there are fewer research studies on teachers' beliefs about the teaching of English and about their attitudes to native speaker teachers (NSTs) and non-native speaker teachers (NNSTs) as well as to new forms of English and to ELF except for very specific and most recent ones (JENKINS, 2005, 2007; MOUSSOU; LLURDA, 2008; DEWEY, 2014; SIFAKIS, 2014; INCEC,̧AY; AKYEL, 2014; ACKERLEY, 2017; CLARK, 2018) on learners' preferences as for NST and NNST, as in the case of the statement in Q21.1 below:

- Q21.1 English language learners prefer to have native speakers of English as their teachers

One of the areas of investigation of the questionnaire, object of Q.21.1, was thus respondents' perception of their learners' preferences in terms of NSTs or NNSTs. The responses in Table 6 reveal that one third of the respondents are unable to position themselves against the statement, most probably because this is still an unexplored field to them, while over one third of the respondents think that their students prefer to have NSTs as their teachers. This response unveils the growing awareness on the part of the teachers of a changing scenario and contribute to confirm what has most often been revealed in previous studies: the perceived inadequacy of the NNSTs model, perceived as negative by learners as well as by teachers themselves. This inadequacy is mostly attributed to their inability to replicate NS pronunciation perceived as the first and most important indicator of second language competence. This is partly revealed by Jenkins (2005, p. 541) in her qualitative study on NNSTs' attitudes to NSs and pronunciation,

[...] Past experiences, both classroom and social, factors in their present situation, and their assessment of their future chances of success may combine to affect their attitudes to English at the deeper level. In some as yet unclear way, these factors may cause them to identify with NSs, or to put it another way, to want a NS English identity as expressed in a native-like accent. Such an accent according to this study's participants is "good," "perfect," "correct," "competent," "fluent," "real," and "original English," whereas a NNS accent is "not good," "wrong," "incorrect," "not real" "fake," "deficient," and "strong. 


\begin{tabular}{|c|c|c|c|c|c|c|c|}
\hline & $\begin{array}{c}0 \\
\text { (Strongly } \\
\text { disagree) }\end{array}$ & 1 & 2 & 3 & 4 & $\begin{array}{c}5 \\
\text { (Strongly } \\
\text { agree) } \\
\end{array}$ & Total \\
\hline $\begin{array}{l}\text { Q21.1 English } \\
\text { language } \\
\text { learners prefer } \\
\text { to have native } \\
\text { speakers of } \\
\text { English as } \\
\text { their teachers }\end{array}$ & $\begin{array}{c}4.29 \% \\
6\end{array}$ & $\begin{array}{c}3.57 \% \\
5\end{array}$ & $\begin{array}{c}22.86 \% \\
32\end{array}$ & $\begin{array}{c}34.29 \% \\
48\end{array}$ & $\begin{array}{c}20 \% \\
28\end{array}$ & $\begin{array}{c}15 \% \\
21\end{array}$ & 140 \\
\hline
\end{tabular}

- Q21.4 Non-native English language teachers should adopt standard English as their target model

When respondents were asked to respond to a clear-cut statement ${ }^{12}$ on NNS teachers' adoption of standard English as their target model for teaching, almost half agreed (65/140), as shown in Table 7 , even if one third (56/140) positioned themselves in the middle, most probably unable, or better uncertain, whether to choose where to stand This uncertainty unveils an occurring shift in perspective in EL teachers who have begun to question traditional English standard models. It is within this uncertainty, probably a transition intersection, that teachers' reflective process and consideration on the new status of English may be sustained in teacher education courses; once more this indicates a growing awareness of the societal changes and of the unavoidable development of English into a language that is no longer the one they had been learning.

Table 7

\begin{tabular}{|c|c|c|c|c|c|c|c|}
\hline & $\begin{array}{c}0 \\
\text { (Strongly } \\
\text { disagree) }\end{array}$ & 1 & 2 & 3 & 4 & $\begin{array}{c}5 \\
\text { (Strongly } \\
\text { agree) }\end{array}$ & Total \\
\hline $\begin{array}{l}\text { Q21.4 Non- } \\
\text { Native } \\
\text { English } \\
\text { language } \\
\text { teachers } \\
\text { should adopt } \\
\text { standard } \\
\text { English as } \\
\text { their target } \\
\text { model }\end{array}$ & $\begin{array}{c}7.14 \% \\
10\end{array}$ & $\begin{array}{c}6.43 \% \\
9\end{array}$ & $\begin{array}{c}15.00 \% \\
21\end{array}$ & $\begin{array}{c}25.00 \% \\
35\end{array}$ & $\begin{array}{c}27.86 \% \\
39\end{array}$ & $\begin{array}{c}18.57 \% \\
26\end{array}$ & 140 \\
\hline
\end{tabular}

12 This statement was previously analysed from a different perspective, that of teachers' positioning to Standard English, here it is analysed in terms of their attitudes and perceptions. 
- Q21.9 English language teachers should avoid using authentic materials which contain non-standard forms of English

The statement above (Q21.9) is provocatively prescriptive through the use of deontic modality, useful to trigger respondents' reactions, specifically meant to induce teachers' reflection on their practice. The notion of authenticity has been explored and discussed in diverse contexts and on different occasions over the last decades, mostly in terms of the type of constructed vs. authentic language samples as used in course-books, and it is now once more brought under the magnifying glass of recent research on English as a Lingua Franca, a field that challenges the very nature of authenticity and highlights the relevance of social context and the notion of localized language use. Widdowson (1978, p. 9) sustains that no materials are authentic in their own right, rather they need to be authenticated by those using them, i.e. by the learners and by their teachers. More and more there is a need to focus on local contexts, trusting teachers' experience and developing appropriate localized materials and course-books for specific language groups (LOPRIORE, 2017, p. 188). Teachers' responses are clear cut: 90 out of 140 respondents disagree with the statement and it indicates how teachers' daily practices most probably determine their positioning in favour of the need to use authentic materials and how EL teachers are more and more aware of current changes in the English used.

\section{Table 8}

\begin{tabular}{|c|c|c|c|c|c|c|c|}
\hline & $\begin{array}{c}0 \\
\text { (Strongly } \\
\text { disagree) }\end{array}$ & 1 & 2 & 3 & 4 & $\begin{array}{c}5 \\
\text { (Strongly } \\
\text { agree) }\end{array}$ & Total \\
\hline $\begin{array}{l}\text { Q21.9 English } \\
\text { language } \\
\text { teachers } \\
\text { should avoid } \\
\text { using } \\
\text { authentic } \\
\text { materials } \\
\text { which contain } \\
\text { non-standard } \\
\text { forms of } \\
\text { English }\end{array}$ & $\begin{array}{c}42.86 \% \\
60\end{array}$ & $\begin{array}{c}21.43 \% \\
30\end{array}$ & $\begin{array}{c}14.29 \% \\
20\end{array}$ & $\begin{array}{c}10 \% \\
14\end{array}$ & $\begin{array}{c}10 \% \\
14\end{array}$ & $\begin{array}{c}1.43 \% \\
2\end{array}$ & 140 \\
\hline
\end{tabular}


- Q21.6 English language teachers should aim at promoting a "successful user of English" model for their learners

This last statement elicits teachers' positioning on a notion that has rarely been presented this way. Traditionally institutional requirements describe students' achievements in a second language in terms of specific language levels or of a set of itemised knowledge competences inclusive of grammar, lexis, skills or pronunciation. This new way of defining teachers' main aim of their ELT practices, i.e. to promote learners as 'users' of English as well as the notion of 'successful', may have elicited a response - as the data in Table 9 show - by which 98 out of 140 respondents clearly position themselves in agreement with the statement. The uncertainty shown by over $20 \%$ of respondents who neither agree or disagree reveals what has already emerged in previous responses: we are facing a shift in EL teachers' perception of the real nature of their job as language teachers as well as their awareness of the changes occurring in the 'subject' they are teaching, i.e., English.

\section{Table 9}

\begin{tabular}{|c|c|c|c|c|c|c|c|}
\hline & $\begin{array}{c}0 \\
\text { (Strongly } \\
\text { disagree) }\end{array}$ & 1 & 2 & 3 & 4 & $\begin{array}{c}5 \\
\text { (Strongly } \\
\text { agree) }\end{array}$ & Total \\
\hline $\begin{array}{l}\text { Q21.6 English } \\
\text { language } \\
\text { teachers should } \\
\text { aim at } \\
\text { promoting a } \\
\text { "successful user } \\
\text { of English" } \\
\text { model for their } \\
\text { learners }\end{array}$ & $\begin{array}{c}1.43 \% \\
2\end{array}$ & $\begin{array}{c}2.86 \% \\
4\end{array}$ & $\begin{array}{c}5 \% \\
7\end{array}$ & $\begin{array}{c}20.71 \% \\
29\end{array}$ & $\begin{array}{c}30 \% \\
42\end{array}$ & $\begin{array}{c}40 \% \\
56\end{array}$ & 140 \\
\hline
\end{tabular}

The emerging results from the four subsections on teachers' personal perceptions elicited teachers' personal stance and positioning as for diverse issues and unveiled their attitudes and deeply held beliefs regarding English, ELT and their perception of language and of language norms.

\section{CONCLUSION}

The analysis of the responses to one of the main questions of the survey administered within the small-scale national research study - among the first 
ones investigating language teachers' attitudes and beliefs towards ELF, has highlighted how the current changes occurring in the last twenty years in the status of English have - at different levels and in diverse modes - begun to influence EL teachers' perceptions, attitudes and everyday classroom practice, in Italy. These first results have shed light upon these teachers' emerging ELF awareness and suggest implications and possible paths in EL teacher education.

The survey carried out so far has shown that standard English is still considered the uncontested reference model in ELT by a large majority of respondents, thus revealing that language education is essentially centred, albeit theoretically, on the monolingual paradigm of EFL. Nevertheless, data also indicate that in terms of teaching practice the notion of English as a closed system is actually changing. Findings regarding: a) the correction of learners' errors (i.e. deviations from standard norms); b) learners' creative power in language use also defined 'lingual capability' by Widdowson (2015); c) the assessment and evaluation of learners' competences; d) learners' preferences in terms of NS and NNS; e) the perception of authenticity as well as f) the understanding of standard models of English, paint a far more complex picture of the way teachers cope with the current multicultural dimension of second language development. It seems reasonable to conclude that respondents' tendency to stick to nativespeakerism is gradually giving way to a more open-minded approach to language variability, which is inherent to the process of language acquisition. Larsen-Freeman (2016, p. 22) contends that: "[...] there is a certain degree of both conformity and creativity in learners' linguistic performance." This combination, we may observe, is also typical of ELF and WE, and could therefore be considered a convergence point of the way the process of L2 learning unfolds in the English classroom, and the way the emergence of ELF takes place in a growingly multilingual and multicultural communicative contexts as, for example, it is the case in Italy.

The responses emerging from this part of the survey underline the need to use English language classroom-based research whereby teachers and learners together contribute to revisit ELT and the urgent need to reframe ELT pre- and in-service teacher education courses (LOPRIORE, 2016), as well as the growing need to sustain EL teachers' awareness of WE and of ELF. The concept of "ELF awareness", as defined by Sifakis $(2014,2017,2018)$ is a way of integrating ELF within ELT. Becoming ELF aware means becoming aware of the observations and principles that emerge from understanding how English language is 
currently used. “The use of an ELF-aware perspective would demand a view of English as a social practice and a better understanding by teachers and learners of the inherent language variability and diversity of English. These conceptions should be reflected within EL teacher education programs, moving beyond the "native/non-native" distinction, opening up to non-native English, thus widening the borders of language awareness" (LOPRIORE, 2018, p. 162).

This, we think, may open a new frontier in teacher education, whereby the findings of ELF research could be exploited to implement projects focused on the pedagogical implications of an ELF-aware approach in the language classroom. As a starting action deriving from this survey, a blended teacher education course informed by the national survey results was devised by the Roma Tre team, and run in 2018 at Roma Tre University, whereby WEs and ELF acted as course embedded notions all through the course components and the approach adopted was meant to engage the participants in a reflective process, to develop their knowledge, skills, attitude and awareness in order to make their own informed choices in ELT and to develop their professional identity as NNES teachers of English.

\section{REFERENCES}

ACKERLEY, K. What the Students Can Teach Us About EMI and Language Issues. In ACKERLEY, K.; HELM, F.; GUARDA, M. (Ed.), Sharing Perspectives on English-Medium Instruction. Bern: Peter Lang, 2017, p. 57-284.

BAYYURT, Y. Non-native English language teachers' perspective on culture in English as a Foreign Language classroom. Teacher Development, v. 10, n. 2, p. 233-247, 2006.

BRAINE, G. Nonnative speakers and invisible barriers in ELT. In TESOL Matters, v. 2, n. 2, 14, 1998.

CLARK, C. The case of the non-native speaker in EMI. In COONAN, C.; BIER, A; BALLARIN, E. (Ed.). La Didattica delle Lingue nel Nuovo Millennio. Venezia: Edizioni Ca' Foscari, 2018, p. 563-576.

DEWEY, M. Pedagogic Criticality and English as a Lingua Franca. Atlantis, v. 36, n. 2, p. 11-30, 2014.

FREEMAN, D. Educating Second Language Teachers. Oxford: Oxford University Press, 2016. 
FREEMAN, D; RICHARDS, J. (Ed.). Teacher Learning in Language Teaching. Cambridge: Cambridge University Press, 1996.

GOLOMBEK, P. A study of language teachers' personal practical knowledge. Tesol Quarterly, v. 32, n. 3, p. 447-464, 1998.

GRAZZI, E. The integration of ELF and sociocultural theory via network-based language teaching: Best practices for the English classroom. In LANTOLF, J. P.; POEHNER, M. E.; SWAIN, M. (Ed.), The Routledge Handbook of Sociocultural and Second Language Development. New York (NY): Routledge, 2018, p. 422-440.

GRAZZI, E.; LOPRIORE, L. ELF \& WE awareness in ELT: non-native Italian teachers' perspectives. RILA-Rassegna Italiana di Linguistica Applicata, n. 1, gennaio-aprile 1-2019, Rome, p. 27-42, 2019.

HOLLIDAY, A. The struggle to teach English as an international language. Oxford: Oxford University Press, 2005.

INCEÇAY, G.; AKYEL, A. S. Turkish EFL Teachers' Perceptions of English as a Lingua Franca. Turkish Online Journal of Qualitative Inquiry, v. 5, n. 1, p.1-12, 2014.

JENKINS, J. Implementing an International Approach to English Pronunciation: The Role of Teacher Attitudes and Identity. Tesol Quarterly, v. 39, n. 3, p. 535 -542, September 2005.

JENKINS, J. The Phonology of English as an International Language. Oxford: Oxford University Press, 2000.

JENKINS, J. English as a Lingua Franca: Attitude and Identity. Oxford: Oxford University Press, 2007.

LANTOLF, J. P.; THORNE, S. L. Sociocultural Theory and the Genesis of Second Language Development. Oxford: Oxford University Press, 2006.

LARSEN-FREEMAN, D. A Successful union. Linking ELF with CAS. In LOPRIORE, L.; GRAZZI, E. (Ed.), Intercultural communication - New perspectives from ELF. Rome: Roma TrE-Press, 2016, p. 15-29.

LLURDA, E. (ed.) Non-native language teachers: Perceptions, challenges, and contributions to the profession. New York: Springer, 2005.

LOPRIORE, L. ELF in teacher education: A way and ways. In LOPRIORE, L.; GRAZZI, E. (Ed.). Intercultural communication - New perspectives from ELF. Rome: Roma TrE-Press, 2016, p. 167-188. 
LOPRIORE L. Revisiting language teaching materials in a time of change. A Cor das Letras, v. 18, Special Issue, p. 182-199, 2017.

LOPRIORE, L. ELF in ELT education: new paradigms in language awareness. In: ELFawareness in ELT: Bringing together theory and practice. Journal of English as a Lingua Franca, v. 7, n. 1, p. 160-166, 2018.

LOPRIORE, L. (Ed.) New Englishes and ELF: investigating teachers' attitudes and ELT in the Italian context, RILA, v.1, Special Issue, Rome, p. 21-74, 2019a.

LOPRIORE, L. New Perspectives in ELT: Teachers' attitudes and identities, Part 1 of ELF \& WE awareness in ELT: non-native Italian teachers' perspectives. In: LOPRIORE, L. (Ed.). New Englishes and ELF: investigating teachers' attitudes and ELT in the Italian context. RILA, v.1, Special Issue, Rome, p. 35-42, $2019 \mathrm{~b}$.

MOUSSU, L.; LLURDA, E. Non-native English-speaking English language teachers: History and research. Language Teaching, v. 41, n. 3, p.315-348, 2008.

NEWBOLD, D. J. The Shape of Tests to come. Idee in Form@Zione, v. 6, p. 41-58, 2018.

OECD. Creating Effective Teaching and Learning Environments: First Results from TALIS Teaching Practices, Teachers' Beliefs and Attitudes, 2009. Available at: $<$ www.oecd-ilibrary.org/education/creating-effective-teaching-and-learningenvironments/teaching-practices-teachers-beliefs-and-attitudes_9789264068780-6-en>. Access: July 15, 2019.

OECD. Uno sguardo sull'istruzione 2016 [Education at a Glance 2016]. Available at: $<$ www.oecd.org/education/skills-beyond-school/EAG2016-Italy.pdf $>$. Access: July 25, 2019.

OECD. Education at a Glance 2018. Available at: <www.oecdilibrary.org/education/education-at-a-glance-2018/italia_krtq2x-it>. Access: July 25, 2019.

PAVLENKO A. Autobiographic narratives as data in Applied Linguistics. Applied Linguistics, v. 28, n. 2, p. 163-188, 2007.

PENNYCOOK, A. Plurilithic Englishes. Towards a 3D model. In MURATA, K.; JENKINS, J. (Ed.). Global Englishes in Asian contexts - Current and future debates Basingstoke: Palgrave Macmillan, 2009, p. 194-207.

PITZL, M-L. Creativity meets convention. Idiom variation and re-metaphorization in ELF. Journal of English as a Lingua Franca, v. 1, n. 1, p. 27-55, 2012.

PRODROMOU, L. English as a Lingua Franca, London: Continuum, 2010. 
SEIDLHOFER, B. (Ed.). Controversies in Applied Linguistics. Oxford: Oxford University Press, 2003.

SIFAKIS, N. ELF awareness as an opportunity for change: A transformative perspective for ESOL teacher education. Journal of English as a Lingua Franca, v. 3, n. 2, p. 317-335, 2014.

SIFAKIS, N. ELF awareness in English Language Teaching: Principles and processes. Applied Linguistics, v. 40, n. 2, p. 288-306, 2017.

SIFAKIS, N. Introduction. In ELF-awareness in ELT: Bringing together theory and practice. Journal of English as a Lingua Franca, v. 7, n. 1, p. 155-160, 2018.

VYGOTSKY, L. S. Mind in Society. The Development of Higher Psychological Processes. Cambridge (MA): Harvard University Press, 1978.

WIDDOWSON, H. Learning Language as Communication. Oxford: Oxford University Press, 1978.

WIDDOWSON, H. Bilingual competence and lingual capability. Plenary talk given at the International Conference on Bilingualism. Malta: University of Malta, 2015. Available at: <www.um.edu.mt/events/bilingualism2015/keynotespeakers>. Access: July 25, 2019.

Enrico Grazzi is associate professor of English at the University of 'Roma Tre', Department of Foreign Languages, Literatures and Cultures. His main interests are English as a lingua franca (ELF), educational linguistics, and sociocultural theory (SCT). His research is based on a Vygotskian approach to second language development, particularly as regards intercultural competence and innovative learning activities (e.g. fanfiction and telecollaboration). Grazzi's main publications are: a) Grazzi, E. 2013, The Sociocultural Dimension of ELF in the English Classroom, Rome: Editoriale Anicia; b) Grazzi, E. 2018, Trajectories of Change in English Language Teaching. An ELF-Aware Approach, Trento: Tangram Edizioni Scientifiche. Grazzi is a qualified teacher trainer and textbook writer. He is a past President of TESOL Italy (2002-2004), a member of AIA (the Italian Association of Anglistics), a member ELF-ReN (the English as a Lingua Franca Research Network, and a member of CultNet (a network of interculturalists in foreign language education). 
Lucilla Lopriore, full professor, Roma Tre University. MA TEFL, Reading University; PhD, Siena University. TESOL Italy President (1996-98), TESOL Intl. Directors Board (2001-2004), TESOL Intl. Research Council Chair (2017). 4 national research projects component/local coordinator, Italian coordinator of the European ELLiE Project (2006-2010), and of the ERASMUS+KA2-ENRICH project (2018/21). Several grants recipient (British Council, Fulbright, Council of Europe); she qualified as Teacher Educator (UK, 1988; USA, 1989) and has run numerous in- and pre-service courses for English, CLIL, and Italian L2 teachers. A coursebook writer: General English at different school levels, ESP and Teaching methodology. Current fields of interest: English as a Lingua Franca (ELF), Teacher Education, Data Driven Learning (DDL), Educational Linguistics, Assessment and evaluation, Early Language Learning, Content and Language Integrated Learning (CLIL). She published extensively in the fields of teacher education, early language learning, ESP, ELF, CLIL and assessment.

Nota do editor: Artigo submetido para avaliação em: 03/03/2019. Aprovado em sistema duplo cego em: 05/11/2019. 